\title{
O altar no laboratório: a CiênCIa e o sagrado no projeto Genoma Humano
}

\author{
Guilherme José da Silva e SA ${ }^{*}$
}

resumo: A linguagem adotada pelos meios de divulgação científica para se referir ao Projeto Genoma Humano (PGH) e a nova genética cunhou termos como "Livro da Vida", "Santo Graal da Biologia", "Linguagem de Deus", que foram utilizados para caracterizar a importância e a dimensão do empreendimento. $\mathrm{O}$ uso de metáforas religiosas não se restringe aos meios de divulgação científica, e se verifica também nas declarações de políticos e cientistas influentes no Projeto. Neste trabalho exponho alguns termos e declarações a respeito do PGH que permitem pensar sobre a relação entre ciência e religião e sobre a utilização de metáforas no discurso científico.

palavras-chave: Projeto Genoma Humano, antropologia da ciência, metáforas religiosas. abstract: Language adopted by scientific media to refer the Human Genome Project (HGP) and the new genetics had used terms like "Book of life", "Holly Graal of Biology", and "Language of God". These expressions were used to characterize the importance and the dimension of this Project (HGP). The use of religious metaphors is not restrict to scientific media, but is also seen in political and scientists speech in the context of the HGP.

In this paper, I intend to show some terms cited about the HGP that are useful to think the relationship between science and religion, and think about the presence of metaphors in scientific discourse.

key-words: Human Genome Project, anthropology of science, religious metaphors.
(...) Então, o que é ciência? Ela é um golem.

(...) Golem é uma criatura da mitologia judaica.

É um bumanóide feito de barro e água por meio de encantamentos e feiticaria. Ele époderoso e vai se tornando mais poderoso com o passar dos dias. Obedece ordens, faz seu trabalho e protege você da constante ameaça do inimigo,

* Doutorando do Programa de Pós-graduação em Antropologia Social / Museu Nacional - UFRJ. mas é desajeitado e perigoso; sem controle, pode destruir os amos com sua agitada vitalidade.

(Collins \& Pinch, 2003:19-20)

A linguagem adotada pelos meios de divulgação científica para se referir ao Projeto Genoma Humano (PGH) e à nova genética usou termos como "Livro da Vida", "Santo Graal da Biologia", "Linguagem de

artigos 
Deus" para caracterizar a importância e a dimensão desse empreendimento. Contudo, o uso de metáforas religiosas não se restringe aos meios de divulgação científica, mas aparece também nas declarações de políticos e cientistas influentes no Projeto.

Neste trabalho apresento alguns termos utilizados e declarações a respeito do PGH que permitem pensar sobre a relação entre ciência e religião e sobre o uso de metáforas no discurso científico. Utilizo a noção de análise do discurso desenvolvida por Foucault, segundo a qual deve-se estudar discursos reais, pronunciados, considerados como práticas que se relacionam a outros níveis não-discursivos (Portocarrero, 1994). Trabalhando a dispersividade discursiva existente no contexto da realização do Projeto Genoma Humano, exponho o discurso de políticos, jornalistas, religiosos, filósofos, bem como o discurso interno das instituições envolvidas, representado, na maioria das vezes, pela palavra dos cientistas. Minha fonte de pesquisa é o discurso de divulgação científica sobre o PGH. Esse tipo de discurso tem sido sistematicamente preterido por análises epistemológicas da ciência, que se interessam fundamentalmente pelo que consideram o "oficial" e deixam de lado os discursos tidos como "oficiosos".

Para os estudiosos da ciência, que muitas vezes assumem uma postura mais "bard" do que a das próprias ciências que estudam, o conceito de algo "oficial" é freqüentemente confundido com a idéia de "pureza" dos dados e das fontes. A divulgação científica aparece, portanto, como um meio "impuro" no qual o discurso científico já está maculado pelos interesses da mídia, da opinião pública, do senso comum, das crenças e das "paixões". Do outro lado - e efetivamente o que me interessa - estão os discursos "oficiosos" que dão conta das minúcias do cotidiano da vida social. Através deles é possível empreender uma antropologia da ciência que veja as pessoas ao mesmo tempo em que lide com os cientistas e as teorias. A evidência da "contaminação" desse discurso "oficioso", bastante rico em nuances, por outros sistemas de representação pode fornecer um vasto material sobre quem faz e para que se faz ciência, além de dar pistas sobre possíveis mecanismos de legitimação da "ciência oficial" na sociedade.

Entretanto, antes de abordar o tema central deste trabalho - as articulações entre religião e ciência no Projeto Genoma Humano - é preciso contextualizar historicamente o PGH.

Em 1953, Watson e Crick descobriram que o ácido desoxirribunucleico (DNA) carregava suas informações dentro de espirais de uma hélice dupla (Wilkie, 1994: 14). A partir dessa descoberta elaborou-se uma das mais sólidas proposições da história das ciências: "o DNA carrega a 'informação genética' e os genes 'produzem seus efeitos' providenciando, assim, as 'instruções' para a síntese protéica. $\mathrm{O}$ DNA faz o RNA, o RNA faz proteínas e as proteínas nos [homens] produzem" (Keller, 1995:18). O raciocínio deflagrado por esses estudos se parece com o que suscitou a iniciativa de pesquisar o genoma humano: "se todo desenvolvimento são apenas instruções preexistentes codificadas nas seqüências de nucleotídeos do DNA e nossos genes nos fazem o que somos -, faz sentido dizer que a identificação dessas 
seqüências constitui o primeiro e último objetivo da Biologia" (Keller, 1995: 21). É possível situar uma linha do tempo desse momento (1953) até 50 anos depois: o término do seqüenciamento.

Em 1984, Sinsheimer propõe a criação de um instituto para o seqüenciamento do genoma humano. A partir de então, a idéia de um esforço coletivo e organizado para mapear e seqüenciar genes humanos começou a ganhar força no meio acadêmico. Em função de seus programas nucleares, o Departamento de Energia dos Estados Unidos (DOE) começou a se interessar pela possibilidade de seqüenciar o genoma humano. Esse órgão sempre considerou os estudos sobre mutações e genética humana um braço importante do seu campo de atuação. Em março de 1986, o Office of Health and Environmental Research (OHER) promoveu um grande encontro científico em Santa Fé (Novo México), quando se obteve o apoio necessário à implementação da idéia do seqüenciamento do genoma humano.

Em 1986, o National Research Council (NRC) delineou as bases para a realização do Projeto Genoma Humano enquanto um empreendimento internacional liderado pelos Estados Unidos: enfatizava-se a proposta de um Atlas genético envolvendo do mapeamento prévio ao seqüenciamento de toda a cadeia de DNA humana - para o qual se estimava o dispêndio de verbas anuais de 200 milhões de dólares durante quinze anos.

Watson veio a participar do debate sobre o planejamento do Projeto Genoma Humano, ponderando que ele deveria ser liderado pelos National Institutes of Health (NIH). Em 1988, foi convidado para o cargo de diretor das pesquisas do genoma humano nos NIH. Na ocasião, foi assinado um acordo de cooperação entre os National Institutes of Health e o Department of Energy. Assim foi lançado o Projeto Genoma Humano dos Estados Unidos $^{1}$. O mesmo ocorreu em outros países (Grã-Bretanha, Japão, França, Alemanha), tornando necessária a criação de um foro de discussão - a Human Genome Organization (HUGO) - para coordenar as pesquisas internacionais e concentrar esforços para analisar a estrutura do DNA humano e determinar a locação de todos os genes.

Em junho de 1991, a revista Science publica o artigo de Craig Venter "Seqüenciamento de DNA Complementar: etiquetas de seqüência expressa e o Projeto Genoma Humano", que apresenta uma nova estratégia de seqüenciamento. Venter funda The Institute for Genomic Research (TIGR), para coletar informações a serem patenteadas e utilizadas por uma empresa "irmã": a Human Genome Sciences.

Em abril de 1992 Watson é substituído por Francis Collins, que assume o cargo em um momento crítico em que se discutiam questões como "a quem pertence o genoma humano?", "quem terá acesso aos frutos da pesquisa?”. Em 1996, no I Encontro Internacional de Estratégia para o Seqüenciamento do Genoma Humano, ratificou-se que: "Todas as informações do seqüenciamento do genoma humano devem ser de domínio público e estar gratuitamente disponíveis para encorajar a pesquisa e o desenvolvimento, e com isso maximizar o

1 Embora a aprovação do Projeto pelo Congresso norteamericano seja datada de 1988, o Projeto Genoma Humano começou oficialmente em 1990 com um orçamento de 60 milhões de dólares para aquele ano. 
seu benefício para a sociedade" (Apud Davies, 2001:136).

Em maio de 1998, saindo do TIGR e fundando uma nova empresa - a Celera Genomics - Craig Venter dispôs-se a seqüenciar todo o genoma humano anos antes do prazo previsto: poderia cobrir todo o genoma humano de forma mais rápida, ainda que restassem diversas lacunas na seqüência. Essa empresa surgiu como a concorrente privada do Consórcio Público do Genoma.

A possibilidade de patentear, lucrar e monopolizar as informações obtidas com o seqüenciamento do genoma humano era veementemente reprovada pelos cientistas envolvidos no PGH e pela opinião pública. Segundo Jonh Sulston, do Sanger Centre (Grã-Bretanha), as informações do genoma não deveriam ser patenteadas por serem "intrinsecamente parte de todo ser humano, uma herança comum que todos partilhamos igualmente" (Apud Davies, 2001:143).

Em abril de 2000 foi feito o anúncio oficial do término do seqüenciamento completo de um genoma humano. A Celera acabara de obter cerca de 30 milhões de fragmentos de DNA; faltava montá-los na seqüência dos cromossomos. Essa declaração foi encarada com descrédito pelo consórcio público, que, em dezembro de 1999, havia publicado na revista Nature a primeira seqüência completa de um cromossomo humano ${ }^{2}$.

Este conflito, ameaçando o futuro do PGH, tornou necessária a intervenção do presidente dos EUA, que ordenou que seu conselheiro científico se empenhasse em

2 Cromossomo 22 restabelecer os objetivos comuns entre o projeto público e a iniciativa privada. Foi então promovida uma reunião conciliatória entre Francis Collins e Craig Venter.

No dia 26 de junho de 2000, o presidente Bill Clinton, Francis Collins, Craig Venter e o primeiro-ministro britânico Tony Blair anunciaram a conclusão do "rascunho grosseiro" feita pelo Consórcio Público do Genoma e da "primeira montagem" da seqüência fornecida pela Celera. Esse anúncio determinava um empate entre o consórcio público e o privado, contemporizando seus objetivos. O número de contratos entre universidades e a Celera passou a aumentar e o Consórcio Público do Genoma deu prosseguimento à pesquisa a partir do "rascunho" já obtido, buscando um aprimoramento da seqüência, o que só foi concluído em 2003.

\section{A "escrita divina": linhas tortas do} DNA

"Hoje estamos aprendendo a língua em que Deus criou a vida. Estamos cada vez mais admirados diante da complexidade, beleza e maravilha do dom mais divino e sagrado de Deus [...] A ciência moderna tem confirmado o que primeiro aprendemos com as crenças antigas. O fato mais importante da vida nesta terra é a nossa humanidade comum." Assim declarou o presidente dos Estados Unidos, Bill Clinton, quando foi divulgado o término do rascunho do seqüenciamento do código genético humano, em 26 de junho de 2000. O comentário do líder político do principal país responsável por levar a cabo o Projeto Genoma Humano (PGH) não pareceu

cadernos de campo - n. $12 \cdot 2004$ 
dissonante à declaração de Francis Collins, responsável pelo Consórcio Público do Genoma, que, ladeado por Craig Venter presidente da Celera Genomics -, acompanhava o presidente. Collins refletiu: "É para mim motivo de humildade e admiração [...] perceber que captamos o primeiro vislumbre de nosso livro de instruções, antes só conhecido por Deus". $\mathrm{O}$ argumento divino também foi evidente no discurso de Collins quando ele se referiu à investigação de genes de doenças como a possibilidade de "apreciar algo que até então nenhum ser humano conhecia, mas Deus sabia [...] De certo modo, talvez, esses momentos de descoberta também se tornam momentos de culto" (Apud Davies, 2001) $)^{3}$.

Creio que essas citações captam bem uma característica do discurso em torno do Projeto Genoma Humano: recorrer a argumentações divinas e imagens bíblicas para expor os fundamentos do que pode ser considerado o projeto mais ambicioso de biotecnologia do século XX. Contudo, este não é um discurso uníssono, tampouco mais destacado do que os demais.

No texto "Artificialidade e Iluminismo" Paul Rabinow disserta sobre o PGH e analisa como nossas práticas e éticas sociais irão mudar à medida que este projeto avance (Rabinow,1999). Não

3 "Cientistas, inclusive alguns muito famosos, perturbados pelas aporias com as quais se confrontam às vezes certas teorias científicas contemporâneas e pelo fato destas parecerem contestar as próprias categorias com os quais o pensamento científico apreende o mundo, ultrapassaram a linha divisória entre ciência e religião e estiveram, de certa forma, à frente da corrente que acreditava na convergência entre a nova ciência e a religião. Por outro lado, não podemos de nenhum modo ver aí o indício de uma continuidade possível entre as novas descobertas científicas e certas extrapolações de caráter mais ou menos religioso." (Champion, 2001:34). pretendo ir tão longe em minhas inferências. Concordo que estamos lidando com novos tipos de racionalidade e que é importante apreciar as representações sobre o Projeto Genoma Humano através dos discursos de argumentação e divulgação pública dos atores nele envolvidos. Para isso, é preciso buscar pistas que nos revelem indícios das práticas e éticas sociais relevantes para aqueles que atuaram diretamente na construção desse conhecimento. Nesse sentido, exponho as evidências discursivas científicas que aludem a imagens caras a tradições religiosas como re-significantes e articuladores de um mundo contínuo.

Não estando restrito somente às declarações presidenciais, o diálogo entre geneticistas e teólogos já havia sido verificado em ocasiões como a Segunda Conferência Norte-Americana sobre Genética, Religião e Ética. Nessa ocasião, W. French Anderson manifestou a opinião de que "a engenharia genética deve limitarse a elementos quantificáveis do corpo e não se envolver com elementos não quantificáveis do espírito ou 'alma"'. Por outro lado, alguns argumentos revelam uma convergência entre a teologia e a genética. É o que expõe James Gustafson, apontando para "a concepção compartilhada sobre a moralidade de certas pesquisas e terapias genéticas e a significância e uso do conhecimento genético para interpretar a natureza, o significado, e o valor da vida humana". (Human Genome News, September 1992; 4(3)). As relações entre a religiosidade e os novos produtos das descobertas genéticas foram motivo de debate nos fóruns das Ethical, Legal and Social Implications (ELSI), onde procurouse explorar formas de interação desse novo

\section{artigos}


conhecimento genético com uma variedade de perspectivas filosóficas, teológicas e éticas.

A idéia vivificada no discurso de cientistas e políticos permanece comprometida com a noção universal de humanidade una, em que o apelo a categorias como "natureza" e "espírito" humano é reforçado por argumentações místico-religiosas. Motivados por temas como "significado" e "função", os questionamentos de religiosos, biólogos e mesmo cientistas sociais por vezes convergem, embora suas opiniões não sejam consensuais. Nesse cenário [pós/a]-moderno, vemos biólogos a procura de subsídios religiosos que enfatizem e dêem a justa dimensão de suas descobertas, religiosos buscando argumentos científicos para antigas doutrinas e mesmo (re)articulando sua linguagem em função dessas provas e cientistas sociais mediando e observando as implicações dessas relações na sociedade, que, em última análise, gerencia suas próprias demandas por explicações, sejam elas científicas ou religiosas.

As recentes descobertas sobre nosso genoma reforçam as evidências sobre a unidade humana, ao mesmo tempo em que especificam as diferenças entre o Homo sapiens e outras espécies. Em um primeiro momento, como indica Matt Ridley, a diferença mais evidente entre os genomas de humanos e chimpanzés está no número de cromossomos: 23 pares em humanos e 24 pares em chimpanzés. Segundo Ridley, o indicativo de ancestralidade comum entre essas espécies indica que uma fusão citogenética nos cromossomos humanos possa ser responsável por nossa diferenciação evolutiva. De acordo com o autor, em decreto do papa João Paulo
II, uma "descontinuidade ontológica" teria dado origem à Humanidade, sendo justamente essa junção cromossômica a localização dos genes que constituem a alma (Apud Davies, 2001: 261).

Hoje, com o fim da leitura da seqüência do DNA humano, estima-se que sejamos 99,9\% semelhante geneticamente aos nossos "parentes" chimpanzés. Se a lógica da "descontinuidade ontológica" se confirmar, nossos genes constitutivos da "alma" representam a ínfima parcela de $0,1 \%$ de nosso genoma. A constatação, feita em tom de brincadeira, serve para expressar relações complexas entre corpo e alma, humano e não-humano e indica a flexibilidade da adoção e interpretação do argumento científico em outros sistemas de representação, como o religioso. Nesse caso, a aliança ciência-religião pode ser creditada a uma tomada de consciência que faz com que a ciência e os cientistas sejam vistos, agora, "como detentores não só de verdades parciais e fragmentadas mas de verdades sobre o sentido do mundo e do homem" (Champion, 2001:31). Mas será essa tomada de consciência algo de fato recente?

Retomando um tema bastante explorado pela metafísica ocidental ${ }^{4}$, o biólogo molecular Alex Mauron indica a "alma" como um fator constitutivo de todos os organismos vivos e determinante

4 De acordo com a dicotomia cartesiana, a mente pensa, e o corpo, objetificado, não. Já o conceito aristotélico de "alma" preserva nesta uma determinada concretude, o que se distancia da concepção de Descartes, para quem a alma seria fundamentalmente abstrata. Descartes reservava à teologia os cuidados com a alma, e julgava que a ciência deveria voltar suas atenções para o corpo. Considerando uma possível ligação entre mente e corpo, Descartes ainda preserva uma hierarquia da mente sobre a matéria/ corpo, uma visão que sugere algo de teocêntrico em seu pensamento, mas que, sobretudo, revela a proximidade entre religião e ciência à sua época (Strathern, 1996).

cadernos de campo ' n. 12 - 2004 
de seus traços característicos. Traçando um paralelo entre o "genoma" - a "impressão digital da natureza humana" - e a "alma" - "cápsula da essência humana" -, Mauron localiza e critica uma espécie de "metafísica genômica" sedimentada com o término do seqüenciamento do genoma humano, que entende o genoma como sinônimo de nossa humanidade. De acordo com essa lógica, o genoma é visto como o cerne de nossa natureza, que determina tanto nossa individualidade como a identidade de nossa espécie (Science, vol. 291, n. 5505, 2001: 381-2). Essa imagem bipartida, característica da "metafísica genômica", foi bastante explorada por alguns geneticistas (Keller, 1995: XV). para os quais as duas faces sobre o gene, metade átomo, para os fisicistas, e metade alma platônica, faziam parte de uma lógica associada à ação dos genes de acordo com a qual se concebia "primeiro o gene, depois a vida", ou ainda, a noção de que com o gene vem a vida (Keller, 1995:9).

A composição da alma inspirou diversas histórias repassadas por gerações de antropólogos para contrapor a natureza à cultura em aulas introdutórias à disciplina. Conforme apontado num conhecido relato, enquanto os europeus discutiam se os índios recém contatados possuíam alma, os referidos habitantes do Novo Mundo submergiam cadáveres durante dias para saber se a carne de "homem branco" entrava em estado de putrefação (Lévi-Strauss, 1976: 334). No artigo "O Superorgânico", Alfred Kroeber faz a seguinte menção à oposição "corpo x alma":
Tem sido modo de pensamento característico de nossa civilização ocidental uma formulação de antíteses complementares, um equilíbrio de contrários que se excluem. Um desses pares de idéias com que o nosso mundo vem lidando há cerca de dois mil anos se exprime nas palavras 'corpo' e 'alma'. Outro par que já teve sua utilidade, mas de que a ciência está agora muitas vezes se esforçando por descartar-se, pelo menos em certos aspectos, é a distinção entre o físico e o mental. Há uma terceira discriminação que é entre o vital e o social, ou, em outras palavras, entre o orgânico e o cultural." (Kroeber, 1949: 232-3).

Longe de querer reificar antigas oposições - tais como alma e corpo ou religião e ciência -, o que sugiro aqui é que a crença no corpo diz respeito ao religioso tanto quanto a fé na descoberta diz respeito à alma do cientista.

\section{Em busca do "cálice sagrado"}

Remete à tradição cristã a mais célebre metáfora associada ao Projeto Genoma Humano: o Santo Graal. Cunhada por Walter Gilbert, biólogo molecular de Harvard premiado com o Nobel em 1980, a expressão "Santo Graal da Biologia" ganha projeção na fase de argumentação para a implementação do Projeto. Em carta endereçada a Robert Edgar, em 1985, Gilbert escreveu: "A seqüência humana completa é o Graal da genética humana toda informação possível sobre a estrutura humana é revelada (mas não entendida). Seria uma ferramenta incomparável para a 
investigação de todo aspecto da função humana" (Apud Cook-Deegan; 1994: 88). A contribuição retórica de Walter Gilbert ao debate sobre o genoma mostrou ser mais pertinente do que se podia prever. $\mathrm{O}$ mito do Graal conferia uma imagem pronta: cada um dos cavaleiros da Távola Redonda saía à procura de um objeto de forma indeterminada, cuja a história era obscura e a função controversa. Assim, cada cavaleiro que tomava parte de uma diferente tarefa, encontrava uma aventura diferente (Cook-Deegan; 1994: 88). A analogia com o Projeto Genoma Humano comparava seus principais cientistas e articuladores a cavaleiros medievais.

Do ponto de vista da estratégia para a implementação do Projeto, o uso da metáfora do Santo Graal foi de grande importância. Para Keller, as palavras não têm força por si próprias: "Elas adquirem força somente através de sua influência em atores humanos. Através de sua influência sobre cientistas, administradores e agências de fomento, fornecem poderosos incentivos para mobilizar recursos, para identificar agendas de pesquisa particulares, para focar nossas energias científicas em direções particulares"(Keller, 1995: 21). Visto dessa maneira, o "Santo Graal da Biologia" constituiu um ótimo chamariz para o PGH, dando a ele um símbolo e concedendo à empreitada uma motivação nobre. O PGH, a essa altura, já possuía homens, imagens e ideais.

A visão do genoma humano como o "Livro do Homem" e a comparação de sua decodificação à busca pelo Santo Graal proporcionaram ao Projeto Genoma Humano grande projeção na mídia, pois tais analogias se baseavam em uma simbologia bem estruturada na cultura popular. Fatalmente, a analogia converteuse em uma transferência de significação. A procura por um objeto sagrado tão representativo do espírito humano acabava por levar, no senso comum, a uma idéia de natureza humana reificada em nosso corpo, especificamente no genoma humano. Estranha armadilha do destino. Enquanto cientistas rejubilavam-se com o espírito elevado "brincando de ser Deus", temiase que, entre a população geral, ressuscitassem antigas doutrinas preconceituosas de cunho fisicalista, que pudessem questionar a "nossa imagem e semelhança".

Contudo, a menção figurativa ao Santo Graal também recebeu críticas de cientistas como o geneticista Richard Lewontin, da Universidade de Harvard.. Para ele: "É um sinal seguro de seu desconhecimento da religião revelada que uma comunidade científica com uma alta concentração de ateus e judeus do leste europeu tenha escolhido para sua metáfora central o objeto mais carregado de mistério do cristianismo medieval". Lewontin repreendia aqueles que faziam do DNA um fetiche, e censurava o "entusiasmo evangélico do moderno templário e a inocência dos acólitos jornalísticos a quem catequizavam". Na opinião de Lewontin, isso resultou na metamorfose do DNA, que passou de uma molécula inerte a uma planta do determinismo biológico, o manual dos humanos (Apud Davies, 2001:26-7).

A crítica de Lewontin vai além do valor da metáfora do "Graal", ele contestou a fetichização da molécula de DNA. Segundo ele, era preciso vê-la como um

cadernos de campo - n. $12 \cdot 2004$ 
elemento que compõe um amplo sistema de relações, que incluíam outros elementos, como o ambiente. A centralização do debate em torno de um único fator constituía uma predisposição reducionista (Lewontin, 1993). Do ponto de vista ético, do impacto sobre os grupos sociais, eram temidos os efeitos do raciocínio reducionista da fetichização da molécula de DNA e de sua onipotência. Porém, sob outro olhar, a utilização de metáforas religiosas só veio a vascularizar a metalinguagem dos laboratórios, proliferando termos, criando novos sujeitos-objetos e vulgarizando o que era sagrado através de um processo de sociabilização de inteligibilidades.

O simbolismo da arte sacra cristã concebe "que no cálice está simbolizado o homem, que fica de pé no chão e ao mesmo tempo como que com braços estendidos se abre para o alto para deixar-se encher por Deus. O que ele recebe, torna a derramar para outros. É, de mais a mais, imagem do destino humano, na medida que o homem recebe da mão de Deus o seu destino como um cálice" (Heinz-Mohr, 1994: 71). Esta definição ilustra bem a idéia de que o "cálice sagrado" concorre para o entendimento do PGH como um empreendimento que tinha como pano de fundo o aprofundamento de questões como "natureza" e "espírito" humano. Craig Venter já chamara a atenção para o fato de que a obtenção da seqüência de DNA seria apenas o início, bem como a procura mitológica do Santo Graal não se encerrava na busca por um tesouro material. Encontrar a relíquia implicaria trilhar uma viagem de transformação pessoal. O que estava em jogo era um processo de autoconhecimento. Decodificar o código genético apresentava-se como uma atualização de um pensamento fisicalista antigo, de acordo com o qual as respostas para nossas questões estariam em nosso próprio corpo.

A comparação com o Graal é bastante pertinente se dissecarmos seu potencial comparativo dentro de uma ciência do concreto (Lévi-Strauss, 1962). O Santo Graal e o genoma humano são símbolos bem estruturados em sistemas de lógica ativa na sociedade ocidental: o primeiro para a narrativa místico-religiosa e o segundo para a ciência moderna. Ambos constituem elementos centrais de seus sistemas, deflagrando buscas, e acabam por se tornar fins na medida em que os caracterizamos como processos de construção e representação cosmológicas de seus próprios sistemas. Entretanto, os paralelos devem ser deixados de lado para destacar o ponto de convergência entre o cálice e o genoma, que se encontra na dimensão reificante da natureza humana, seja em um objeto que possui uma interpretação artística e morfológica análoga ao corpo humano, ou através do genoma humano em sua expressão fisicalista.

O fisicalismo se baseia numa velha proposição de cunho geralmente reducionista, que percorre a história das teorias sobre a gênese e o comportamento do ser humano no pensamento ocidental. A relação estabelecida entre o homem e seu corpo em busca de respostas sobre sua humanidade tomou forma - inclusive em roupagens científicas - de oráculo, enciclopédia e marcador de diferença. Diversas foram as teorias científicas que 
utilizaram o corpo humano para justificar suas hipóteses, construir seus argumentos e chegar a suas conclusões. Essa vertente de pensamento entende que o corpo humano consiste num sistema perfeito e que o organismo responde por qualquer idiossincrasia do indivíduo. Tom Wilkie chama a atenção para a tendência voltada para este pensamento fisicalista e a idéia de que o Projeto Genoma Humano fornecerá respostas, evidentemente limitadas, para perguntas sobre a natureza do homem. Wilkie expõe:

\section{Inicialmente voltado para o entendimento de doenças genéticas que afligem o ser humano, o Projeto Genoma Humano também toma novos rumos, o interesse de pesquisadores direciona-se para a chamada 'genética funcional'. Mas as ramificações do projeto hoje em andamento em laboratórios e institutos de pesquisa do mundo todo vão muito além de um mero interesse por doenças. Alguns de seus defensores têm feito afirmações exageradas: que o Projeto Genoma Humano nos permitirá compreender, no nível mais fundamental, o que é ser homem. Ao mesmo tempo, porém, há o temor legítimo de que tamanha ênfase na constituição genética da humanidade possa distorcer nosso senso de valores e nos levar a esquecer que a vida humana é mais que a mera expressão de um programa genético escrito na química do DNA (Wilkie, 1994:13).}

De fato, o PGH não responderá "o que é ser humano", mas acredito que, explorando os meandros dessa "ciência sacralizada" por seus discursos, é possível evidenciar um lado mundano e oficioso de uma ciência feita por seres humanos.
Ainda que intimamente associada ao Projeto Genoma Humano, a imagem do Graal identifica-se com outros ramos da ciência moderna: "Para os físicos, o Graal é a identificação de um dos tijolos fundamentais da matéria. Os biofísicos consideram que o Graal é a previsão da estrutura tridimensional completa de uma proteína, a partir de sua cadeia unidimensional de tijolos. Os químicos invocam o cálice sagrado na sua busca para criar um elemento artificial altamente estável" (Davies, 2001: 26-7). A extensão da metáfora do Graal nos leva a pensar em outros projetos de amplitude similar no alcance e na representatividade desses projetos, considerados big science, para a sociedade ocidental. É isso que Svante Pääbo se pergunta, inserindo o PGH no contexto das grandes descobertas. "Por que certas conquistas - a chegada à Lua, a fissão atômica, a determinação da seqüência do genoma humano - estão imbuídas de tamanha significância emblemática? A razão é, creio eu, que elas mudam a maneira como nós pensamos sobre nós mesmos. (...) A seqüência do genoma humano nos dá uma visão do aparato genético interno no qual toda vida humana é moldada" (Science, 2001: 12191220; v.291,n.5507).

Lévi-Strauss já indicava um caminho que conflui para o entendimento de que esses projetos fazem parte de uma lógica auto-representativa da construção cosmológica da sociedade ocidental:

Assim, os eventos que os especialistas imaginam para auxiliar-nos a cruzar o abismo que se criou entre a experiência macroscópica e verdades inacessíveis ao 
leigo - big-bang, universo em expansão etc. - possuem todo o caráter dos mitos. A ponto de, como mostrei em relação aos mitos, o pensamento lançado numa dessas construções gerar imediatamente o seu universo. É o caso da noção de um universo fadado, segundo os cálculos, a se dilatar infinitamente, ou a se contrair até desaparecer. (...) Durante alguns séculos, a ciência foi dominada pela idéia de um tempo reversível, de um universo imutável em que o passado e o futuro eram idênticos de direito. Só restava a história para servir de refúgio ao pensamento mítico. $\mathrm{E}$ eis que ficamos sabendo, primeiramente pela teoria da evolução e depois pela nova cosmologia, que o universo e a vida também estão na história; que tiveram um começo e estão entregues ao devir. Ao mesmo tempo, surgem problemas tão imensos que esse saber incontestável nos faz duvidar de que possamos algum dia compreender o que havia antes, o que haverá depois ou como as coisas realmente ocorreram. Parece tão difícil admitir que milhares de acontecimentos, todos altamente improváveis, tenham, em algo como 7 milhões de anos, garantido a passagem de um mundo desprovido de toda e qualquer vida a um mundo de RNA inicialmente, em seguida um mundo de DNA, que mesmo especialistas ilustres são obrigados a forjar mitos. (...) Para o homem, volta a existir, portanto, um mundo sobrenatural. Os cálculos e experiências dos físicos certamente demonstram sua realidade. Mas essas experiências só adquirem sentido quando transcritas em linguagem matemática. Aos olhos dos leigos (ou seja, de quase toda a humanidade), esse mundo sobrenatural apresenta as mesmas propriedades que o dos mitos: tudo acontece de um modo diferente do que no mundo comum e, freqüentemente, ao inverso. Para o homem comum - todos nós - esse mundo permanece inatingível, exceto pelo viés de velhos modos de pensar que o especialista consente em restaurar para o nosso uso (e às vezes, infelizmente, para o seu próprio). Do modo mais inesperado, é o diálogo com a ciência que torna o pensamento mítico novamente atual. (LéviStrauss, 1993: 11-2).

A analogia entre o caráter dos mitos e a ciência aproxima Lévi-Strauss à uma antropologia simétrica proposta por Latour \& Woolgar (1997) - e aplicada em sua etnografia de um laboratório de biotecnologia - para a qual a ciência representa o eixo central e o argumento fundante na forma de ver e pensar o mundo e a si próprio na sociedade ocidental.

\section{Outras articulações}

A renovação dos discursos místicoreligiosos permeados pelo vocabulário científico, inclusive, em religiões historicamente tradicionais, parece ter sido acompanhada por uma mudança na forma de crer e de expressar a fé. Novos credos surgem fundamentados em informações e práticas que misturam misticismo e ciência. $O$ caso recente que atingiu maior destaque na mídia foi o da seita dos "Raelianos". Esse grupo de seguidores de "Rael", homem que diz ter sido abduzido por extraterrestres, acredita que os seres humanos foram criados por extraterrestres por meio de clonagem e que esta seria o primeiro passo para a vida eterna. 
Argumentando, também, que Jesus Cristo teria sido um "clone perfeito", os Raelianos anunciaram, em dezembro de 2002, através da empresa norte-americana Clonaid, o nascimento dos primeiros bebês clonados do mundo. O caso foi encarado com ceticismo pelo meio científico, mas alcançou grande projeção na mídia não só pelo ineditismo do feito (ou farsa) científico, como também pela intenção em continuar clonando seres humanos em função de uma crença religiosa. Nesse caso, o controle da prática científica encontrase intimamente ligado à crença de um determinado grupo que não é composto exclusivamente por cientistas.

A lógica não seria muito distinta dos primórdios do pensamento científico, ainda muito restrito e dependente das possibilidades oferecidas pela religião, não fosse o cenário moderno fragmentado entre ciência e religião. A proposição moderna de compartimentação de saberes e de dimensões da vida cotidiana não comportaria esse tipo de interferência. Não creio, porém, que a reconstrução, releitura ou atualização das cosmologias religiosas, utilizando-se de subsídios fornecidos pela ciência moderna, representem um sinal de laicização de seu discurso, mas sim que trazem efetivamente mudanças em suas práticas. Champion chama a atenção para o surgimento do que denominou de "nebulosa místico-esotérica", que, entre os anos 1970 e 80, pretendia apresentar um "novo paradigma", compreendendo "uma visão surpreendente do mundo, nascida da convergência entre descobertas científicas mais recentes e concepções milenares das diversas tradições místicas" (Champion, 2001: 27). Ao contrário das correntes religiosas internas ao cristianismo e ao judaísmo, que reificavam a linha divisória entre fé e ciência, no pensamento místicoesotérico "a questão cosmológica não se dissocia em absoluto da questão antropológica. Ora, a questão cosmológica coloca de saída o problema do saber científico como conhecimento do cosmos (em sentido amplo), conhecimento este que é hoje parte de nossas percepções e de nossas categorias de pensamento correntes. $\mathrm{O}$ praticante místico-esotérico, explicitamente, contesta a ciência (clássica) e o mundo que ela concebeu: mundo fragmentado, abstrato, determinado, mecanicista, quantificado e indiferente ao homem" (Champion, 2001:29). Se, tradicionalmente, associávamos a religiosidade a uma descrença nos mecanismos propostos pela ciência formal e o cientificismo a um completo ceticismo, hoje podemos dizer que tanto a ciência tem possibilitado que pessoas "creiam melhor", quanto as imagens religiosas têm contribuído para que o ofício de cientistas se torne cada vez mais inteligível e socialmente legitimado.

A adoção de um vocabulário caro a segmentos religiosos por aqueles que desenvolvem a prática científica não configura necessariamente - e como já situei de forma inversa - o deflagrar de um processo de "reencantamento do mundo", no qual a ciência assumiria aura mística ou divina. Tampouco deve-se subestimar a capacidade da ciência de formar opinião. Gostaria de pensar essa questão em função de novas formas possíveis de racionalidade e reflexividade analisando a construção de discursos científicos, e sobre a ciência, contemporâneos e pautados em sistemas de representação. Para esse fim, o conceito de "articulação" trabalhado por Donna 
Haraway, aliado à idéia de que "ciência é cultura", é bastante útil para entender a elaboração do discurso metafórico e as referências religiosas e científicas em foco neste artigo. Assim sendo:

O discurso é somente um processo de articulação. Um mundo articulado tem inúmeros modos e locais onde conexões podem ser feitas. [...] Articular é significar. [...] A articulação deve permanecer aberta, sua densidade acessível à ação e intervenção. Quando o sistema de conexões fecha em torno de si mesmo, quando a ação simbólica torna-se perfeita, o mundo está congelado em uma dança da morte. O Cosmos está acabado e é único. Paranóia é a única postura possível (Haraway,1992).

É através da utilização de metáforas que o discurso científico se atualiza na sociedade na qual se insere, transpondo as fronteiras de seus laboratórios e que a ciência tem contato com outros sistemas de representação socioculturais. De forma semelhante, Donna Haraway conclui seu "Manifesto for Cyborgs" (1985) argumentando que perceber as relações sociais da ciência e da tecnologia consiste em admiti-las como reconstruções e atualizações da vida cotidiana sempre em relação com os diversos sistemas de representação a que estamos expostos.

\section{Considerações finais}

O debate acerca das relações entre ciência e religião é complexo, e coube ao pensamento moderno pensar ambas como sistemas de representação distintos. Não nos cabe, aqui, questionar os parâmetros em que essa separação ocorreu, e ainda ocorre, mas acredito ser importante pensar a forma como se faz e como se fala sobre ciência na atualidade. Nesse sentido, a relação entre o discurso científico e o religioso é pertinente para visualizar um mundo, ou uma percepção de mundo, ocidental menos fragmentado do que se imagina.

Champion sustenta que o triunfo inconteste da eficácia técnica da ciência possibilitou que esta fizesse uso de outras esferas de conhecimento e crença (religião, paraciência, etc.) e, assim, abandonasse a intenção de explicar univocamente o mundo (Champion, 2001:40). Talvez a ciência não se preserve tão laica a ponto de descartar a utilização de imagens tão impregnadas de significado como as religiosas; talvez a religião absorva discursos voltados para o empírico sem prescindir de sua espiritualidade.

De certo, não há espaço aqui, é importante frisar, para um raciocínio utilitarista. Não é a necessidade de subsistência que vai unir sistemas de representação bastante sólidos, que, em certa medida, não se separaram. Uma referência mútua organizada em forma de redes de sociabilidade e significação possibilita o autogerenciamento desse processo. Acredito que o PGH seja um produto desse mundo "híbrido", como quer Latour, ou desse "ambiente", segundo Ingold, composto por várias esferas. A invocação de imagens religiosas associadas a esse tipo de empreitada vai além da pura e simples divulgação científica. O referencial 
místico está intrínseco às motivações da pesquisa. Essas motivações podem ser de caráter pessoal, no que diz respeito às crenças individuais dos cientistas; de marketing, quanto ao interesse na projeção e no financiamento das pesquisas; e mesmo de significação, no que concerne a busca por meios de organizar um raciocínio inteligível para a própria ciência. Este último item, a meu ver, não é exclusivamente voltado à massa leiga para qual a ciência deve ser divulgada e se fazer entendida, mas também serve como referencial criativo para os próprios cientistas, ampliando seu vocabulário possível e trazendo de volta suas conotações do laboratório para o mundo. Em outras palavras, não é a obtenção das cifras, mas, sobretudo, a poética dos significados que unem esses dois sistemas de representação.

Tentei demonstrar, ao correr das linhas, que o PGH é produto de diversas instâncias que unem pesquisas militares a seitas "extraterrestres", técnicos de laboratório a cavaleiros medievais, chefes de estado a máquinas seqüenciadoras, supercomputadores a movimentos sociais, meios de comunicação a políticos, cientistas naturais a cientistas sociais. Tudo está nesse mundo "híbrido", nas "redes" (Latour, 1994). E tudo o que nos resta está no meio. Está entre. Nas relações. Não há significado em uma molécula de DNA sem um ambiente, crítica iniciada por Lewontin e posteriormente trabalhada por Ingold (2000), mas é através dessa relação que ela se significa, ao mesmo tempo que significa o ambiente. Foi justamente na relação entre discursos científicos e religiosos que pretendi situar esta análise sobre o PGH.

Artigo aceito para publicação em 30 de setembro de 2004.

Bibliografia:

CHAMPION, Françoise. Constituição e transformação da Aliança CiênciaReligião na Nebulosa MísticoEsotérica. In: Religião \& Sociedade, vol.21(2), 2001. p. 25-43.

CLINTON, Bill. President's State of the Union Address Refers to Human Genome Project. National Human Genome Research Institute, 1999.

CLINTON, Bill. Communications. National Human Genome Research Institute, 2000.

COLLINS, H. \& Pinch, T. O Golem: O que você deveria saber sobre ciência. São Paulo: UNESP, 2003.

COOK-DEEGAN, R. The Gene Wars: Science, Politics, and the Human Genome. New York: W.W. Norton \& Company, Inc, 1994.

DAVIES, Kevin. Decifrando o Genoma: $A$ corrida para desvendar o DNA bumano. São Paulo: Companhia das Letras, 2001.

HARAWAY, Donna. A Manifesto for Cyborgs. In: Socialist Review, 15, 1985. p. 69.

HARAWAY, Donna. The Promises of Monsters: A Regenerative Politics for lnappropriate/d Others. In: Grossberg, 
Lawrence \& Treichler, Paula (orgs.). Cultural Studies. New York: Routledge, Chapman and Hall, Inc, 1992.

INGOLD, Tim. The Perception of the Environment: Essays on Livelihood, Dwelling and Skill. London/New York: Routledge, 2000.

KELLER, Evelyn Fox. Refiguring Life: Metaphors of Twentieth-Century Biology. New York: Columbia University Press, 1995.

KROEBER, Alfred. O Superorgânico. In: Pierson, Donald (org.). Estudos de organização social. São Paulo: Livraria Martins Editora, 1949.

LATOUR, Bruno. Jamais fomos modernos: ensaio de antropologia simétrica. Rio de Janeiro: Editora 34, 1994.

LATOUR, Bruno \& Woolgar, Steve. A vida de laboratório: a producão dos fatos científicos. Rio de Janeiro: Relume Dumará, 1997.

LEWONTIM, Richard. Biology as ldeology: The Doctrine of DNA. New York: HarperCollins Publishers, 1993.

LÉVI-STRAUSS, Claude. La Pensée Sauvage. Paris: Librairie Plon, 1962.

LÉVI-STRAUSS, Claude. Antropologia estrutural dois. Rio de Janeiro: Biblioteca Tempo Universitário, 1976.

LÉVI-STRAUSS, Claude. História de lince. São Paulo: Companhia das Letras, 1993.
MAURON, Alex. Is the Genome the Secular Equivalent of the Soul?. In: Science, 291, 2001. p. 831-2.

PORTOCARRERO, Vera. Foucault: A história dos saberes e das práticas. In: PORTOCARRERO, Vera. (org.). Filosofia, história e sociologia das ciências I. Rio de Janeiro: Editora Fiocruz, 1994.

RABINOW, Paul. Antropologia da razão: ensaios de Paul Rabinow. Rio de Janeiro: Relume Dumará, 1999.

STRATHEM, Andrew. Body Thoughts. Michigan: University of Michigan Press, 1996.

WILKIE, Tom. Projeto Genoma Humano: um conhecimento perigoso. Rio de Janeiro: Jorge Zahar Ed, 1994.

Second National Conference on Genetics, Religion, and Ethics. Human Genome News, 1992. 
